\title{
Design of Arduino-based small wind power generation system
}

\author{
Abdul Goffar Al Mubarok ${ }^{1, *}$, Wisnu Djatmiko ${ }^{2}$, and Muhammad Yusro ${ }^{3}$ \\ ${ }^{1,2,3}$ Universitas Negeri Jakarta, Faculty of Engineering, Jalan Rawamangun Muka Jakarta Timur 13220, Indonesia
}

\begin{abstract}
Wind energy is a less-attended renewable energy due to the lack of information about its potential. Some pilot wind turbines were not managed properly and built without considering to the technical feasibility. This study aims to propose a preliminary design of an Arduino-based small wind power generation system. The electricity which is generated by the wind charges the battery. It supplies power of information system which transmits the data of wind speed and wind direction from the remote location to the web server through GPRS network. The remote location which is completed with mobile data coverage is essential for this study. The results of this study are (1) the battery charging stop automatically when the battery is full (2) the data of wind speed and wind direction can be accessed through web browser or Android Smartphone. The data can be used for further analysis to determine the potential of wind energy at the site.
\end{abstract}

\section{Introduction}

Today's world is faced with challenging conditions such as the depletion of fossil fuel resources, the increase of carbon emissions, and the global warming [1]. To change from fossil fuel energy use, people are starting to look for alternative energy uses, which are more environmentally friendly solutions[2]. These alternative energy uses renewable recourses not only to reduce the dependence on fossil fuels but also the carbon emission and improve the air quality. Wind energy naturally has become the resource of the fastest growing renewable energy in the worldwide [3, 4].

The wind energy is the air flows resulting from the difference of pressures which is caused by the differences of temperature and density of the air mass in the earth surface which is caused by the sun's heat radiation [5]. The blowing wind contains kinetic energy which can be used to generate electricity power [6]. On the contrary, the wind energy is not gained considerable concern in Indonesia because of the lack information of its potential. In addition, some pilot wind turbines were not properly managed and built without concerning to the technical feasibility. Accordingly, it raised the growing doubts about the potential of wind energy in Indonesia [7].

Naturally, the potential of wind energy in Indonesia is relatively small because it is located in the equator [8] however it is quite good in the range of $3-6 \mathrm{~m} / \mathrm{s}$ with the available resources of $970 \mathrm{MW}$ [7].

Wind power plant is a power plant with the principle of converting the kinetic energy in the wind to the turbine rotary power, and then the power is used to drive a generator which converts to electricity power [9]. The wind turbine is an essential component of wind power generation system. Generally, it is divided into two types: Horizontal Axis Wind Turbine (HAWT) and Vertical Axis Wind Turbine (VAWT) [10], where HAWT is more popular than VAWT[2]. The Generator, a part of wind turbine, is a machine which converts mechanical energy into electricity in order to charges the batteries [11]. The electrochemical reaction of charging and discharging occurs in an electrical energy storage called battery. The charging process works when the battery is functioning as a burden and source of energy from generator. On the other side, the discharging process works when the battery is functioning as the energy source for other expenses [10]. The obstacle on wind power generation system is the fluctuation in the wind speed which causes unstable voltage battery charging. Accordingly, it shortens the battery life [12].

Otherwise, In Indonesia, the mastery of wind turbine technology has not been maximized yet. Accordingly, the intensive research is required in order to develop wind turbines in accordance with the condition of the wind energy potential in Indonesia [8]. This research is aimed to propose a preliminary design of an Arduinobased small wind power generation system. The electricity generated from wind power is used to charge the battery. Furthermore, the battery supply power [13] to information system that transmits the data of wind speed and direction in the remote location to the web server through GPRS network.

\section{Method}

This study was conducted using engineering method proposed by Borg \& Gall [14] which had been adapted to the needs of this research though 4 steps: (1) need analysis, (2) design \& planning, (3) development and (4) test and repair

\footnotetext{
Corresponding author: a.goffar.almubarok@gmail.com
} 


\subsection{Need Analysis}

First, literature and field study were conducted in order to analyze the needs required to achieve the research objectives. The specification system (Table. 1) and diagram block system (Figure 1) were specified.

Table 1. Specification of system.

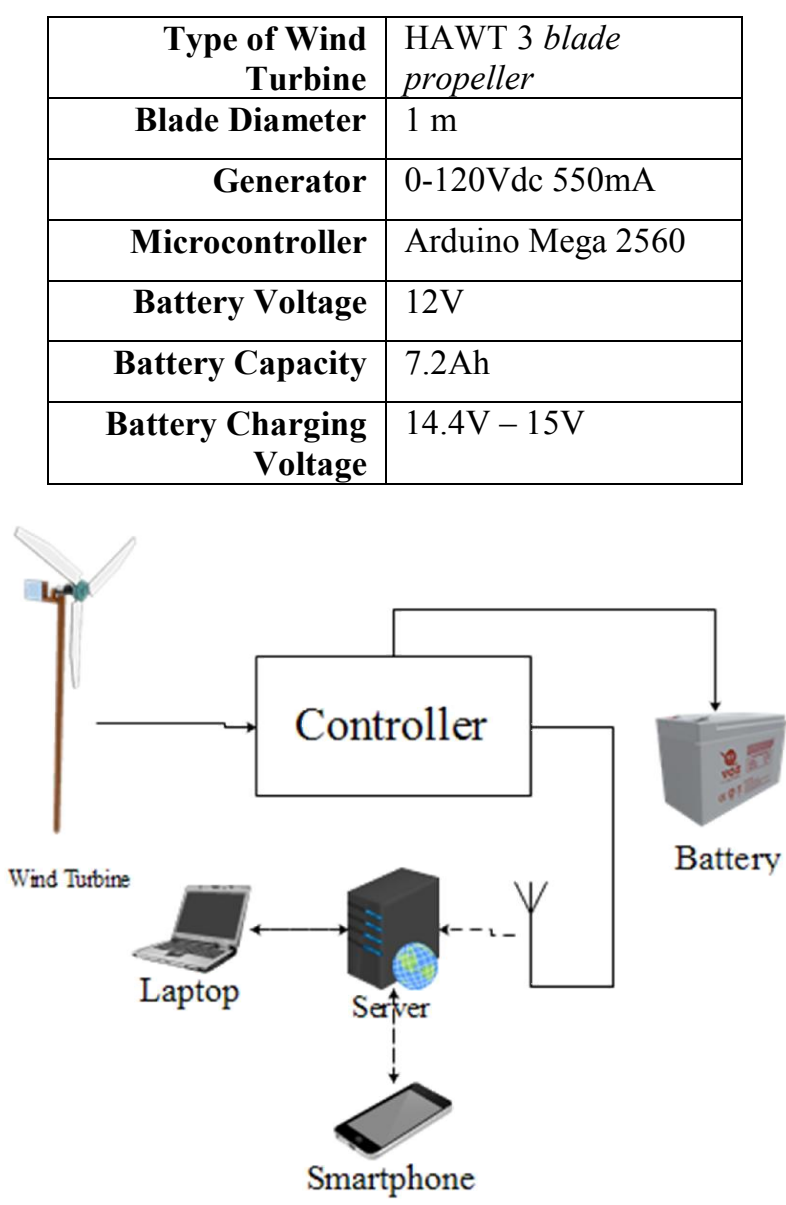

Fig. 1. The block diagram of the system.

\subsection{Planning and Design}

Second, determination and planning of the other system was determined as well as the battery charging control by module buck-boost converter XL6009 and relays, the choice of current sensor, the design of voltage sensor, the design of wind turbine, the determination of voltage regulator for Arduino power supply, the determination of RPM sensor, the determination of anemometer sensor, the determination of wind direction sensor, the determination of communication device in web through GPRS network, the design of programming flowchart for Arduino (Figure 2), the selection of input/output (I/O) for Arduino (Figure 3), and the determination of web server used in the research.

\subsection{Development} manufactured the appropriate program written based on the flowchart, and the integration of hardware and programs.

\subsection{Testing and Repair}

Last, the integrated system was test. The correction and improvement were done to some errors occurred in the system until it worked as expected. Furthermore, the data collecting, data processing and conclusion were conducted.

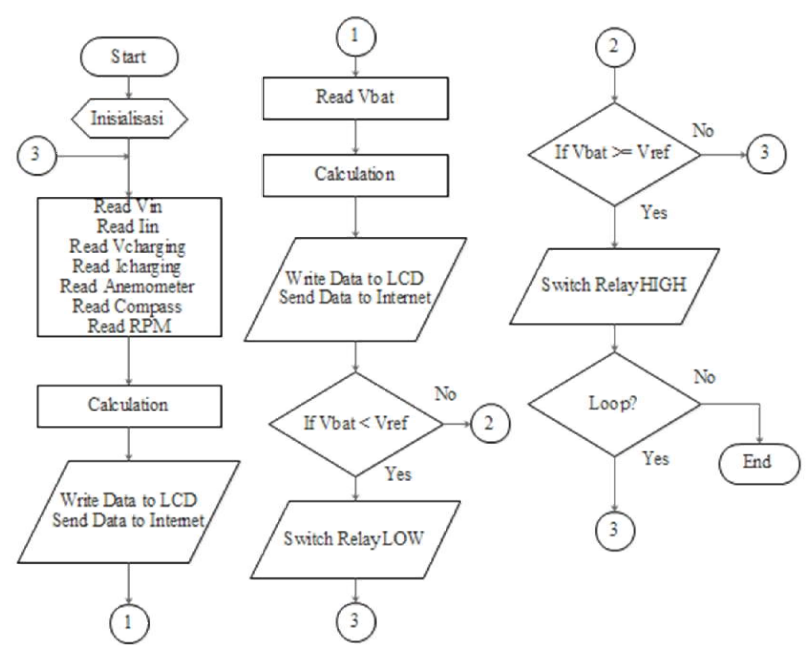

Fig. 2. Programming flowchart.

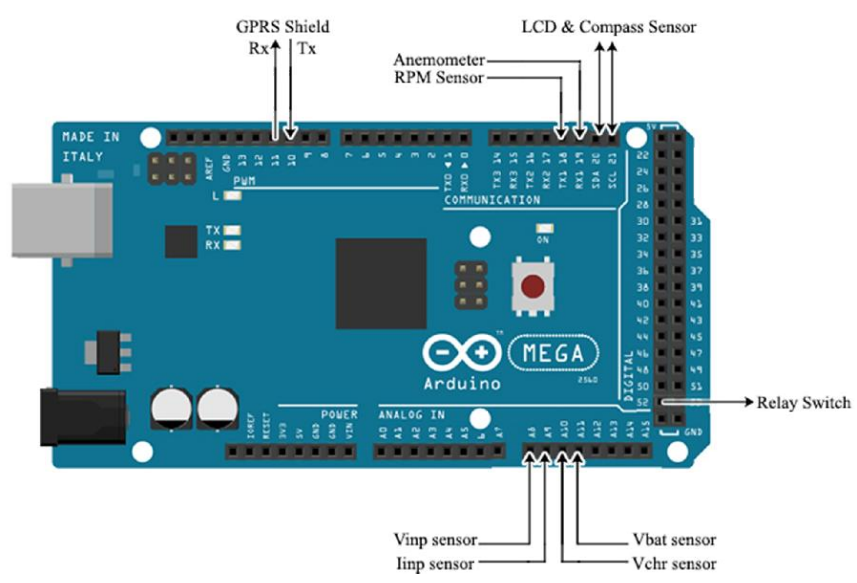

Fig. 3. I/O mapping of Arduino.

\section{Result}

\subsection{The Working Principle of System}

The system converted wind energy into mechanical energy by using wind turbines. The speed of the rotating blade was measured by using RPM sensor. The wind speed was measured by the anemometer. The wind direction was measured by the compass sensor. Then, the mechanical energy was converted into electrical energy by a DC generator. The voltage produced by the DC generator was measured by a voltage sensor, while the electrical current generated was measured by using 
current sensor. The fluctuating voltage, depending on the speed of the wind, was converted by module buck-boost into DC voltage. The output voltage was measured by the voltage sensor. On the other side, the module output current was measured by the current sensor. Then the output voltage was streamed to the battery to commit the charging process. The battery charging will stop when the battery was full [15]. The battery used to supply power to the information system sent the data to the web server. Data stored on the web server was accessed by web client thought laptop or mobile phone. The documentation of design result is shown in Figure 4.

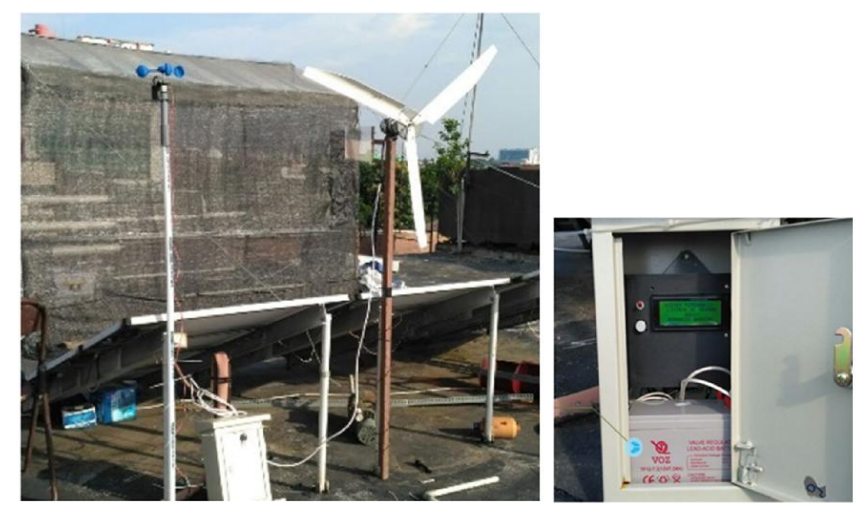

Fig. 4. The documentation of the system.

\subsection{Analysis}

\subsubsection{Testing of the Buck-Boost Converter Module}

The test was conducted with the input power supply voltage range of $0 \mathrm{~V}-20 \mathrm{~V}$. Comparison between the input and output voltage module was conducted as shown in Figure 5 .

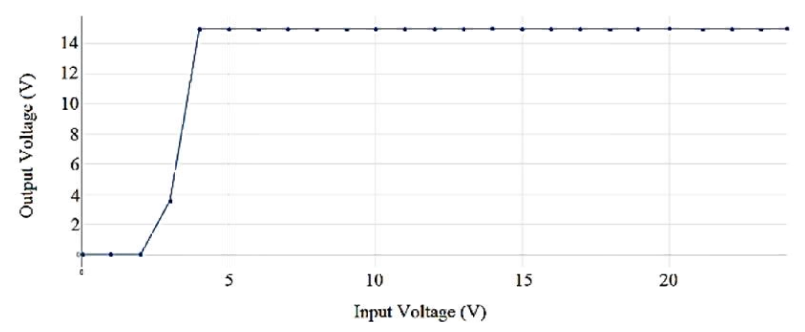

Fig. 5. Results of the buck-boost converter module testing.

\subsubsection{Testing of the Voltage Sensor}

Voltage sensor was tested by measuring the voltage with rage of $15 \mathrm{~V}-24 \mathrm{~V}$. The measurement result of the sensor was compared with the measurement result of digital voltmeter, as shown in Figure 6.

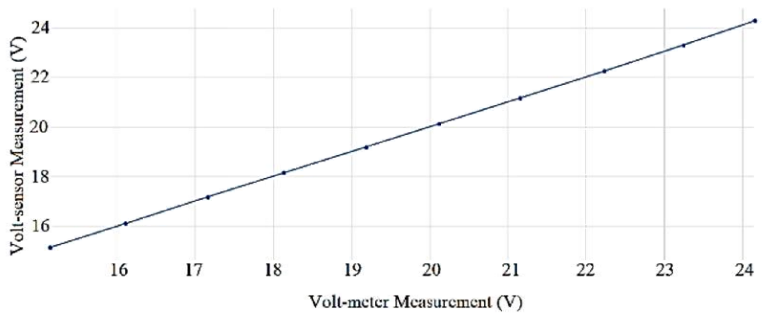

Fig. 6. Comparison of voltage sensor and digital voltmeter.

\subsubsection{Testing of the Relay Switch}

Relay switch was used to disconnect the battery when it was fully charged. The result of relay switch result is shown in Table 2.

Table 2. Results of the relay switch testing.

\begin{tabular}{|l|l|l|}
\hline $\begin{array}{l}\text { Voltage } \\
(V)\end{array}$ & $\begin{array}{l}\text { Relay State Testing } \\
\text { Criteria }\end{array}$ & $\begin{array}{l}\text { Relay State } \\
\text { Testing Result }\end{array}$ \\
\hline $\mathbf{1 1}$ & OFF & OFF \\
\hline $\mathbf{1 1 . 5}$ & OFF & OFF \\
\hline $\mathbf{1 2}$ & OFF & OFF \\
\hline $\mathbf{1 2 . 5}$ & OFF & OFF \\
\hline $\mathbf{1 3}$ & OFF & OFF \\
\hline $\mathbf{1 3 . 5}$ & ON & ON \\
\hline $\mathbf{1 4}$ & ON & ON \\
\hline $\mathbf{1 4 . 5}$ & ON & ON \\
\hline $\mathbf{1 5}$ & ON & ON \\
\hline
\end{tabular}

\subsubsection{Testing of the Current Sensor}

The test was conducted in order to know whether the program and the current sensor module worked properly or not. Current sensor was tested by measuring the current flow that stream from the voltage source of $6 \mathrm{~V}-$ $15 \mathrm{~V}$ and resistance load of $10 \Omega$. The measurement result was compared with the current value displayed in power supply. The test result of MAX471 current sensor is shown in the Figure 7 below.

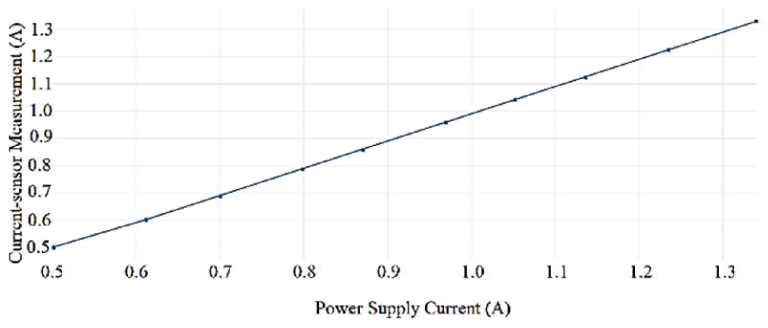

Fig. 7. Results of the MAX471 current sensor testing.

\subsubsection{Testing of Anemometer}

The test was aimed to determine the accuracy of anemometer reading by comparing the sensor reading by handy anemometer, as shown in Table 3.

Table 3. Results of the anemometer testing. 


\begin{tabular}{|c|c|}
\hline $\begin{array}{c}\text { Handy Anemometer } \\
(\mathbf{m} / \mathbf{s})\end{array}$ & $\begin{array}{c}\text { Anemometer (Sensor) } \\
(\mathbf{m} / \mathbf{s})\end{array}$ \\
\hline 0 & 0 \\
\hline 1.9 & 1.91 \\
\hline 2.4 & 2.41 \\
\hline 2.9 & 2.92 \\
\hline 3.0 & 3.02 \\
\hline
\end{tabular}

\subsubsection{Testing of the Wind Direction Sensor}

The comparison of wind resection reading by compass with compass application in smartphone was aimed to know whether the compass sensor worked effectively or not. The results of the compass sensor with HMC5583L magnetometer module testing is shown in the Table 4 below.

Table 4. The results of compass sensor testing.

\begin{tabular}{|c|c|c|}
\hline Direction & $\begin{array}{c}\text { Smartphone } \\
\text { Compass }\end{array}$ & $\begin{array}{c}\text { Compass Sensor } \\
(\text { HMC5583L) }\end{array}$ \\
\hline North & $0^{\circ}$ & $0.04^{\circ}$ \\
\hline North East & $45^{\circ}$ & $45.01^{\circ}$ \\
\hline East & $90^{\circ}$ & $90.16^{\circ}$ \\
\hline South East & $135^{\circ}$ & $135.07^{\circ}$ \\
\hline South & $180^{\circ}$ & $180.03^{\circ}$ \\
\hline South West & $225^{\circ}$ & $225.08^{\circ}$ \\
\hline West & $270^{\circ}$ & $270.02^{\circ}$ \\
\hline North West & $315^{\circ}$ & $315.01^{\circ}$ \\
\hline
\end{tabular}

\subsubsection{Testing of Electricity Generation (No Load)}

Electrical power generation testing was conducted with the condition of under controlled wind by using a wind tunnel. However, in this research, the wind tunnel replaced by a coupled DC motor with a generator. The speed of DC motor rotation declared by RPM unit converted to $\mathrm{m} / \mathrm{s}$ unit was assumed as the wind velocity that turns the turbine for generating electricity from the generator rotation.

It was needed to define the parameters according to equation of equation (1), equation (2) and equation (3) and convert the wind speed into RPM.

$P_{\text {wind }}=\frac{1}{2}\left(\rho \cdot v_{\text {wind }}^{3} \cdot A\right)$

$P_{\text {wind }} \cdot C_{P}=P_{\text {mechanics }}$

$P=\omega \cdot T$

The parameters required were air density ( $\rho)$, the coefficient of performance $(\mathrm{Cp})$, wind turbine torque $(\mathrm{T})$, wind speed $\left(v_{\text {wind }}\right)$, and the angular velocity $(\omega)$. The coefficient of performance was an efficiency of the system which affected the amount of energy that successfully converted by wind turbines and generators. In this study, it was used a wind turbine blade with a radius of $0.5 \mathrm{~m}$ and assumed the value of $\rho$ at $1.37 \mathrm{~kg} /$ $\mathrm{m} 3, \mathrm{Cp}$ of 0.3 , and $\mathrm{T} 0.1 \mathrm{Nm}$. By entering the known variable value, accordingly the value of wind, $v_{\text {wind }}$, and $\omega$ were calculated by combining equation (1) with equation (3) into the equation (4).

$\omega=1.61 \cdot v_{\text {wind }}^{3}$

Figure 8 shows the graph of the output voltage of the generator.

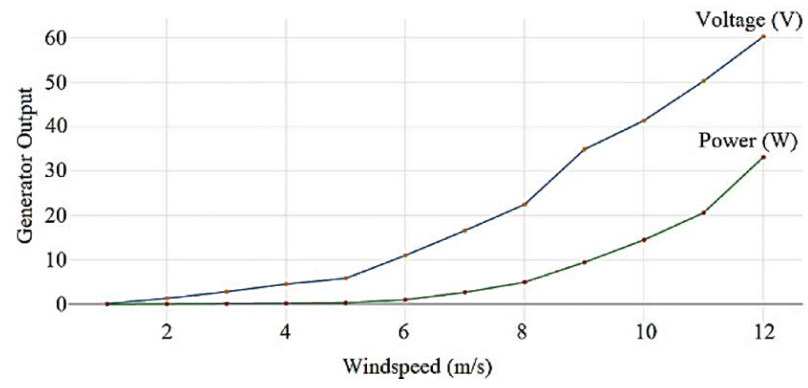

Fig. 8. The relationship between the wind speed and the generator output voltage and power.

\subsubsection{Testing of Battery Charging}

The battery charging test was conducted by converting electrical energy from wind power. Electric energy generation was conducted at 08.00 to 20.00. The Figure 9 shows the graph of battery voltage.

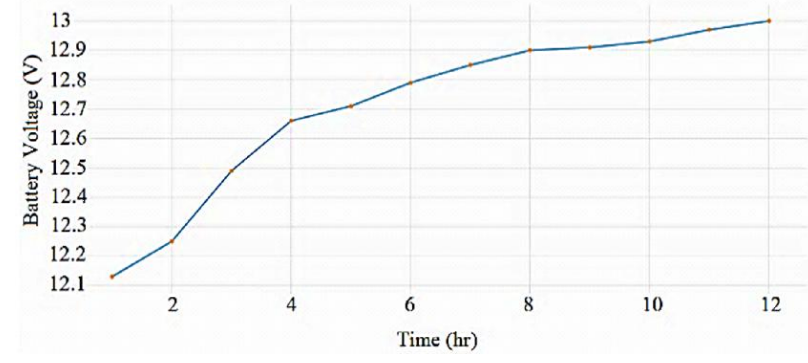

Fig. 9. Battery voltage during the charging process.

\subsubsection{Testing of Battery Discharging}

The system loads powered by the battery were the Arduino Mega 2560, the anemometer sensor, the RPM sensor, the compass sensor, the LCD, and the GSM / GPRS Shield. The test was done start at 08.00 on January 17, 2018 with the initial voltage of the battery of 13 Volts. Figure 10 is a graph of battery voltage when discharging.

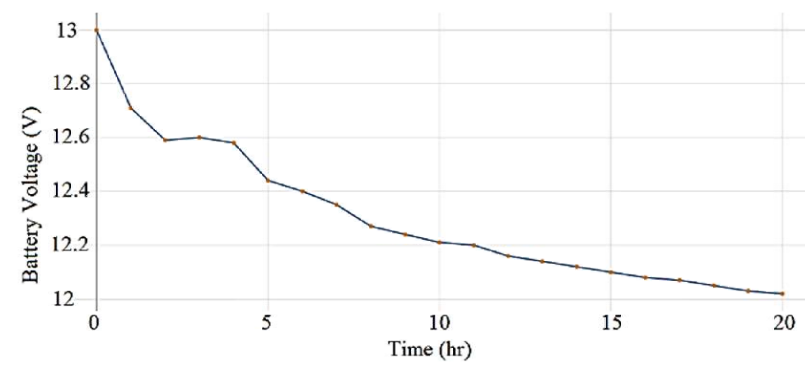

Fig. 10. Battery voltage during the discharging process. 


\subsubsection{Testing of Data Delivery to the Web}

The ThingSpeak sent data can be accessed through a web browser via a link https://thingspeak.com/channels/402026 [16] or through an Android smartphone application, ThingView, by adding the channel 402026. Documentation recording test results and performance data are shown by Figure 11. Figure 12 is a graph of wind speed and Figure 13 is a graph of wind direction that is recorded and sent to the web server.

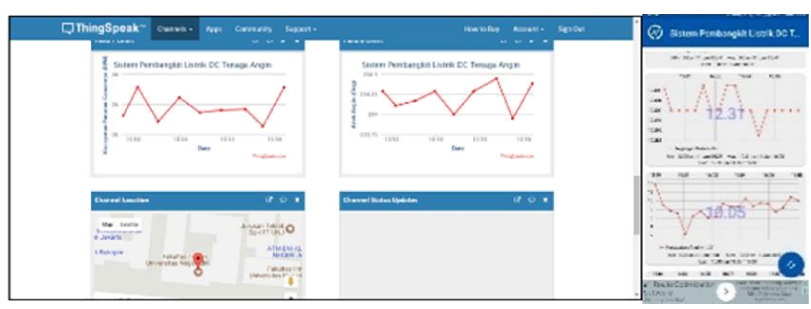

Fig. 11. The system data displayed on a web page and smartphone.

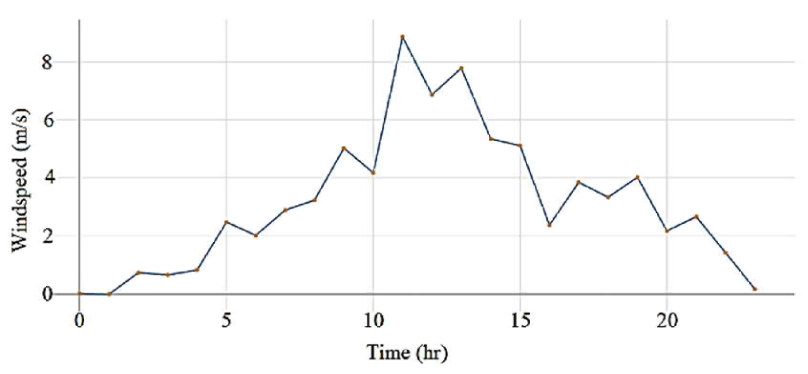

Fig. 12. The wind speed graph.

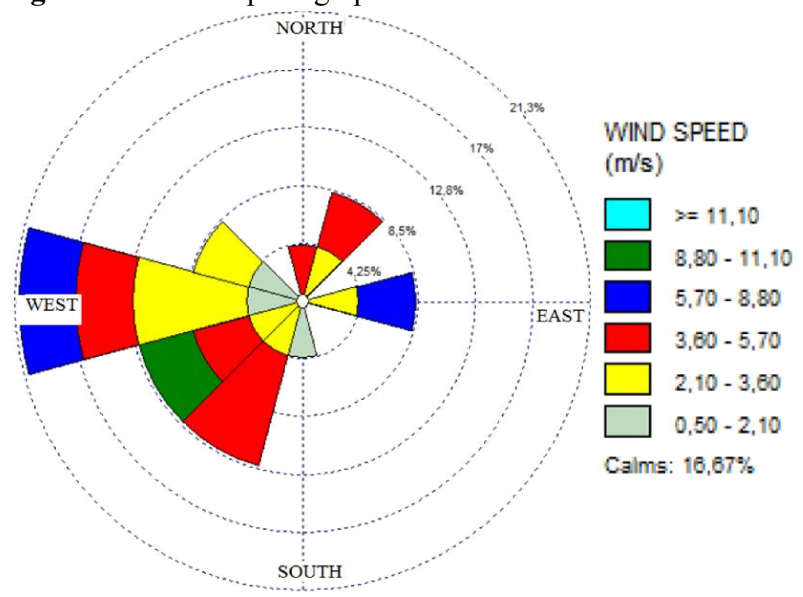

Fig. 13. Wind direction graph (Windrose Diagram).

\section{Discussion}

The test results of the XL6009 buck-boost converter module to keep the $15 \mathrm{~V}$ constant output voltage indicated that the module was working properly. The test results of the voltage sensor indicate that the sensor is working properly. The result of the switch relay test used to disconnect and connect the battery charge voltage revealed that the battery was working properly. The relay stayed in OFF condition when it was given voltage of $11 \mathrm{~V}$ to $13 \mathrm{~V}$. On the other side, the relay turned $\mathrm{ON}$, with an LED as indicator, when it was given voltage of $13.5 \mathrm{~V}$ to $15 \mathrm{~V}$.

The result of anemometer sensor test shows that the anemometer sensor functioned properly. The result of MAX471 current sensor test indicates that the sensor functioned properly. The result of the compass sensor test with HMC5583L magnetometer module revealed that the compass sensor functioned well. The results of the test of electricity generation (no load) indicated that the higher the wind speed, the greater the power generated by the generator, accordingly, the electricity generated was higher. The voltage and power generated by the generator differ when it was given the load, this was the impact of the load on the control loop[17].

The battery charging test with a DC power source from the generator was conducted with the initial battery voltage of 12 Volts. Based on Figure 9, the battery voltage continued to increase over time because it was charged by using a DC power source converted from wind power. Test results revealed that a battery with an initial condition of 13 Volts can supply the load for 20 hours, from 08.00 until 04.00 . The results of testing the recording and appearance of data on the web server in ThingSpeak showed that the data retrieved by the system has been successfully sent and displayed properly on the web server. The data from the web server can be exported into CSV format for further processing and analysis. Figure 11 is a graph of wind direction (Windrose diagram) created with WRPlot View application[18].

\section{Conclusion}

The preliminary research to the paper consists only of the preliminary design, testing and basically, knowledge reference to the general analysis of the future design proposed.

The build and tested preliminary design of Arduinobased small wind power generation system can be applied as a source of DC power source in remote locations which was not covered by electrical grid. Moreover, it can charge the battery of telemetry-based weather station power supplies in remote inaccessible power grid[19] but still covered by GPRS network to transmit the data to a web server.

The data transmitted by the information system and stored on a web server can be used for various purposes, such as forecast the weather, analysis of potential weather wind speed at the location of the placement of the system for research and development of wind power generation in the future.

\section{References}

1. Samrat, N.H., Ahmad, N., Choudhury, I.A., Taha, Z.: Technical Study of a Standalone Photovoltaic - Wind Energy Based Hybrid Power Supply Systems for Island Electrification in Malaysia. 1-35

(2015). 
doi:10.1371/journal.pone.0130678

2. Cho, K., Jeong, S., Sari, D.P.: Harvesting Wind Energy From Aerodynamic Design For Building Integrated Wind Turbines. Int. J. Technol. 2, 189-198 (2011). doi:10.14716/ijtech.v2i3.65

3. Einan, M., Torkaman, H., Pourgholi, M.: Optimized Fuzzy-Cuckoo Controller for Active Power Control of Battery Energy Storage System, Photovoltaic, Fuel Cell and Wind Turbine in an Isolated Micro-Grid. Batteries. 3, 23 (2017). doi:10.3390/batteries3030023

4. Wang, J., Zhou, Q., Jiang, H., Hou, R.: ShortTerm Wind Speed Forecasting Using Support Vector Regression Optimized by Cuckoo Optimization Algorithm. Math. Probl. Eng. 2015, 619178 (2014). doi:10.1155/2015/619178

5. Astu, P., Djati, N.: Mesin Konversi Energi. Andi, Yogyakarta (2013)

6. Contained Energy Indonesia: Buku Panduan Energi yang Terbarukan. (2011)

7. Wargadalam, V.J.: Potensi Energi Angin dan Kelayakan Harga Listrik yang Dihasilkan, (2014)

8. KESDM: Rencana Strategis Ditjen EBTKE. J. Energi Media Komun. Kementeri. Energi dan Sumber Daya Miner. 2, (2016)

9. Aji, S.: Mengenal Pembangkit Listrik Tenaga Bayu (Bagian 1), https://seword.com/techno/mengenalpembangkit-listrik-tenaga-bayu-bagian-1

10. Lentera Angin Nusantara: Pengenalan Teknologi Pemanfaatan Energi Angin, (2014)

11. Sumanto: Mesin Arus Searah. Andi Offset, Yogyakarta (1995)

12. Wahab, W., Ardie, N., Rochman, N.T.: Analysis and Design of a Fuzzy Logic Controlled Buck Boost Converter For a Wind Turbine Power Generation. In: The 7th Indonesia Japan Joint Scientific Symposium. hal. 200-207 (2016)

13. Quevedo, P.M. De, Contreras, J.: Optimal Placement of Energy Storage and Wind Power under Uncertainty. 9, (2016). doi:10.3390/en9070528

14. Sutarti, T., Irawan, E.: Kiat Sukses Meraih Hibah Penelitian Pengembangan. Deepublish, Yogyakarta (2017)

15. Wei, L., Weijia, Z., Jin, P., Qian, N.: Optimal Capacity Allocation of Large-Scale Wind-PVBattery Hybrid System. 2015 7th Int. Conf. Intell. Human-Machine Syst. Cybern. 2014, 420-423 (2015). doi:10.1109/IHMSC.2015.251

16. MathWorks: Learn More About ThingSpeak, https://thingspeak.com/pages/learn_more

17. Lukasievicz, T., Oliveira, R., Toricco, C.: A Control Approach and Supplementary Controllers for a Stand-Alone System with Predominance of Wind Generation. Energies. 11,
411 (2018). doi:10.3390/en11020411

18. Lakes Environmental Software: Wind Rose Plots for Meteorological Data. WRPLOT View. Release Notes, (2016)

19. Mohammadnezami, M.H., Ehyaei, M.A., Rosen, M.A., Ahmadi, M.H.: Meeting the Electrical Energy Needs of a Residential Building with a Wind-Photovoltaic Hybrid System. 2554-2569 (2015). doi:10.3390/su7032554 